\title{
Micro-FTIR and EPMA Characterisation of Charoite from Murun Massif (Russia)
}

\author{
Maria Lacalamita \\ Dipartimento di Scienze della Terra, Università di Pisa, 56126 Pisa, Italy \\ Correspondence should be addressed to Maria Lacalamita; maria.lacalamita@dst.unipi.it
}

Received 21 December 2017; Accepted 20 February 2018; Published 3 April 2018

Academic Editor: Javier Garcia-Guinea

Copyright ( 2018 Maria Lacalamita. This is an open access article distributed under the Creative Commons Attribution License, which permits unrestricted use, distribution, and reproduction in any medium, provided the original work is properly cited.

\begin{abstract}
Combined micro-Fourier transform infrared (micro-FTIR) and electron probe microanalyses (EPMA) were performed on a single crystal of charoite from Murun Massif (Russia) in order to get a deeper insight into the vibrational features of crystals with complex structure and chemistry. The micro-FTIR study of a single crystal of charoite was collected in the $6000-400 \mathrm{~cm}^{-1}$ at room temperature and after heating at $100^{\circ} \mathrm{C}$. The structural complexity of this mineral is reflected by its infrared spectrum. The analysis revealed a prominent absorption in the $\mathrm{OH}$ stretching region as a consequence of band overlapping due to a combination of $\mathrm{H}_{2} \mathrm{O}$ and $\mathrm{OH}$ stretching vibrations. Several overtones of the $\mathrm{O}-\mathrm{H}$ and $\mathrm{Si}-\mathrm{O}$ stretching vibration bands were observed at about 4440 and $4080 \mathrm{~cm}^{-1}$ such as absorption possibly due to the organic matter at about $3000-2800 \mathrm{~cm}^{-1}$. No significant change due to the loss of adsorbed water was observed in the spectrum obtained after heating. The occurrence of well-resolved water bending vibration bands at about 1595 and $1667 \mathrm{~cm}^{-1}$ accounts for more than one structural water molecule as expected by charoite- 90 polytype structure model from literature. The chemical composition of the studied crystal is close to the literature one.
\end{abstract}

\section{Introduction}

Charoite, $\mathrm{K}_{5} \mathrm{Ca}_{8} \mathrm{Si}_{18} \mathrm{O}_{46}(\mathrm{OH}) \cdot n \mathrm{H}_{2} \mathrm{O}$, is a high-valued semiprecious gemstone occurring uniquely in the alkaline rocks of the Murun Massif in Yakutiya, Russia [1]. This rare silicate belongs to the group of the microporous minerals whose structure is based on a mixed tetrahedral-octahedral framework. The increased interest in these compounds came from their potential use as materials alternative to zeolites in different fields, from environmental protection to industrial applications.

The structure of charoite was only recently solved ex novo and "ab initio" in the $P 2_{1} / m$ space group by electron diffraction data $[2,3]$. Two-ordered polytypes with different cell parameters (i.e., the monoclinic "charoite-96" and orthorhombic "charoite-90") were identified inside the sample along with other partially ordered and disordered polytypes (i.e., "charoite-2a" and "charoite-d"). The structure of both charoite-96 and charoite-90 polytypes consists of three different tubular drier silicate chains running along [001] having external and internal diameters comparable to those of carbon nanotubes. The silicate chains are bonded by their apical oxygen to bands of edge-sharing $\mathrm{Ca}$ - and $\mathrm{Na}$ octahedra which also run along [001] forming cavities occupied by extraframework cations ( $\mathrm{K}, \mathrm{Sr}, \mathrm{Ba}$, and $\mathrm{Mn}$ ) and $\mathrm{H}_{2} \mathrm{O}$ molecules. In the charoite-96, adjacent blocks of the three different chains are shifted by a translation of $1 / 2 c$ whereas no shift occur in the charoite- 90 polytype. The asymmetric unit of the charoite-90 contains 90 independent atomic positions among which three $\mathrm{H}_{2} \mathrm{O}$ sites and one $\mathrm{OH}$ site partially occupied by $\mathrm{OH}^{-}$and $\mathrm{F}^{-}$ions [2]. For the monoclinic polytype, 87 atomic positions enclosing only one $\mathrm{H}_{2} \mathrm{O}$ and one $\mathrm{OH} / \mathrm{F}$ sites were refined [3]. A thermal study of charoite revealed that the dehydration (i.e., loss of adsorbed and structural $\mathrm{H}_{2} \mathrm{O}$ ) occurs in the temperature range $80-290^{\circ} \mathrm{C}$ whereas the dehydroxylation processes are observed from 290 to $480^{\circ} \mathrm{C}$ [4].

Apart from the detailed structural characterization, few and incomplete spectroscopic data of charoite have been reported so far in the literature. The RRUFF database contains Raman spectra collected in the range $\sim 1200-100 \mathrm{~cm}^{-1}$ whereas Buzatu and Buzgar [5] provided a wider range of 
Raman signal (from $\sim 4000$ to $200 \mathrm{~cm}^{-1}$ ). However, the last spectrum is characterized by strong fluorescence and noisy background which allow in distinguishing weak peaks mainly in the $\mathrm{Si}-\mathrm{O}$ and $\mathrm{Ca}-\mathrm{O}$ vibration region and in the position of $\mathrm{N}-\mathrm{H}$ vibration $\left(2367,2403 \mathrm{~cm}^{-1}\right.$ ) due to $\mathrm{NH}_{4}{ }^{+}$ions which probably substitutes for $\mathrm{K}^{+}$in the charoite structure. No signal was observed in the $\mathrm{OH}$ stretching region. The infrared spectrum of charoite was reported in comparison to that of canasite in [6]. The authors observe absorption in the $\mathrm{OH}$ stretching and bending regions which accounts for the presence of water molecules in the charoite structure. However, no discussion or defined band assignment was reported being the structure of this mineral not yet clear at the time.

In the present study, micro-FTIR and EPMA were performed on the same single crystal in order to define the characteristic vibrational modes of charoite in the light of the recent structural determination of the mineral.

It is noteworthy that advances in the crystal chemical features of this mineral can help to determine their potential properties such as strengthening glass ceramics, ion exchange, and conductivity [7].

\section{Experimental}

2.1. Sample Description. Charoite occurs in charoitites of the Murun Massif (Yakutia, Russia). The Murun complex, formed at 120-150 Ma and covering an area of about 150 $\mathrm{Km}^{2}$, consists of ultrapotassic agpaitic rocks with carbonatites other than charoitites whose composition varies from alkaline-ultramafic to granitic [8]. Charoite crystallized jointly with other Ca-bearing alkaline minerals, such as frankamenite, canasite, miserite, tinaksite, and tokkoite [9].

The crystal studied here was handpicked under a binocular microscope starting from a fragment of asbestoslike fibers elongated along the $z$-axis. The selected crystal is characterized by light-violet colour and $0.10 \times 0.05 \times 0.02$ $\left(\mathrm{mm}^{3}\right)$ dimensions.

2.2. Analytical Methods. Chemical analysis was carried out on the studied charoite crystal embedded in epoxy resin, polished and then carbon coated. The same crystal was previously subject to micro-FTIR analyses. A JEOL JXA-8200 electron microprobe operating at $15 \mathrm{kV}$ accelerating voltage, $5 \mathrm{nA}$ sample current, $\sim 1 \mu \mathrm{m}$ spot size, and $40 \mathrm{~s}$ counting time was used. Full wavelength dispersive spectrometry (WDS) mode was employed. The used standards for major, minor, and REE components were wollastonite $(\mathrm{Si})$, anorthite $(\mathrm{Al}, \mathrm{Ca})$, omphacite $(\mathrm{Na})$, olivine $(\mathrm{Mg}), \mathrm{K}$-feldspar $(\mathrm{K})$, $\mathrm{Zr}$-jarosite $(\mathrm{Zr})$, ilmenite $(\mathrm{Ti}), \mathrm{Cr}$ pure $(\mathrm{Cr})$, rhodonite $(\mathrm{Mn}, \mathrm{Zn})$, fayalite $(\mathrm{Fe})$, celestine $(\mathrm{Sr})$, sanbornite $(\mathrm{Ba})$, and F-apatite (F). A Phi-Rho-Z routine was employed for the conversion from X-ray counts to oxide weight percentages (wt\%). The average composition was determined over five spots.

Infrared analysis of charoite was performed at room temperature before and after heating the sample at $100^{\circ} \mathrm{C}$ for 4 hours. The measurements were performed on a single crystal mounted on glass capillary and laid on the cleavage plane. The spectra were collected over the range $6000-400 \mathrm{~cm}^{-1}$ using a Nicolet Avatar FTIR spectrometer with a nominal resolution of $4 \mathrm{~cm}^{-1}$, equipped with a Continuum microscope, an MCT nitrogen-cooled detector, and a KBr beamsplitter. The observed IR-patterns resulted from the average of 128 scans. The $\mathrm{OH}$ stretching region $\left(3700-3000 \mathrm{~cm}^{-1}\right.$ ) of the spectrum was modelled using the program Origin $L a b$, assuming Gaussian functions to describe the peaks and a linear function to approximate the background.

\section{Results and Discussion}

The mean weight oxides ( $\mathrm{wt} \%$ ) from EPMA analysis are $\mathrm{SiO}_{2}, 56.1(3) ; \mathrm{Al}_{2} \mathrm{O}_{3}, 0.03(1) ; \mathrm{Na}_{2} \mathrm{O}, 3.5(3) ; \mathrm{MgO}, 0.5(1)$; $\mathrm{K}_{2} \mathrm{O}$, 8.00(3); $\mathrm{CaO}, 20.5(6) ; \mathrm{TiO}_{2}, 0.01(3) ; \mathrm{Cr}_{2} \mathrm{O}_{3}, 0.01(2)$; $\mathrm{MnO}, 1.1(1) ; \mathrm{FeO}, 0.27(7) ; \mathrm{ZnO}, 0.07(9) ; \mathrm{SrO}, 0.08(4)$; $\mathrm{ZrO}_{2}, 0.02(4) ; \mathrm{BaO}, 0.12(6)$; and F, 0.1(1); subtotal 90.5(4) wt $\%$. The chemical formula calculated on the basis of 45 oxygen atoms is $\left(\mathrm{K}_{3.31} \mathrm{Sr}_{0.02} \mathrm{Ba}_{0.02} \mathrm{Mn}_{0.31} \mathrm{Mg}_{0.24} \mathrm{Fe}_{0.07}\right)_{\Sigma}=3.97$ $\left(\mathrm{Ca}_{7.13} \mathrm{Na}_{1.10}\right)_{\Sigma=8.23}\left(\mathrm{Si}_{17.99} \mathrm{O}_{45}\right) \mathrm{F}_{0.10}$, compatible with the ideal chemical formula $\mathrm{K}_{5} \mathrm{Ca}_{8} \mathrm{Si}_{18} \mathrm{O}_{46}(\mathrm{OH}) \cdot n \mathrm{H}_{2} \mathrm{O}$. It is also in good agreement with that published in [2], except for the low amount of $\mathrm{Sr}$ and the enrichment in $\mathrm{Mg}$ and $\mathrm{Mn}$ of the study crystal.

The typical single-crystal nonpolarized room temperature micro-FTIR spectrum of charoite in the 6000$400 \mathrm{~cm}^{-1}$ range is shown in Figure 1. The spectrum collected after heating at $100^{\circ} \mathrm{C}$ is illustrated in Figures 2(a) and 2(b) together with that before heating. The results of fitting of the $\mathrm{OH}$ stretching region of the room temperature spectrum are displayed in Figure 3 whereas the main band positions observed for the studied sample are given in Table 1. The table also contains the literature infrared and Raman data of charoite.

The spectrum in Figure 1 evidences very strong absorption bands at about $600-800 \mathrm{~cm}^{-1}$ and $\sim 1100 \mathrm{~cm}^{-1}$ which are assigned to stretching vibration of $\mathrm{Si}-\mathrm{O}$ and $\mathrm{Ca}-\mathrm{O}$ bonds $[5,10]$. The group of bands in the $2077-1841 \mathrm{~cm}^{-1}$ range are due to the combination of $\mathrm{Si}-\mathrm{O}$ absorption [11]. The most notable feature of the spectrum in Figure 1 is a very broad and intense absorption extending from $\sim 3650$ to $3000 \mathrm{~cm}^{-1}$, peaking at $\sim 3450 \mathrm{~cm}^{-1}$, as a result of internal stretching vibration modes ( $\nu 3$ and $v 1$ ) and bending overtone $(2 v 2)$ of water molecules overlapping with absorptions of $\mathrm{OH}$ groups [12]. The $v 2$ bending modes are centered essentially at about 1595 and $1667 \mathrm{~cm}^{-1}$ (Figure 2(b), Table 1). These findings together with the absence of significant changes in the $\mathrm{OH}$ absorption of the heated sample (compare spectra in Figures 2(a) and 2(b)) suggest that the spectrum of the studied charoite is not affected by the contribution of the adsorbed water. In addition, the two wellresolved bands in the water bending region of the spectrum in Figure 2(b) indicate that more than one water environment occurs in the charoite structure. This feature suggests that the analysed crystal consists essentially of the orthorhombic charoite- 90 polytype which contains three $\mathrm{H}_{2} \mathrm{O}$ sites, that is, $\mathrm{H}_{2} \mathrm{O}(1), \mathrm{H}_{2} \mathrm{O}(2)$, and $\mathrm{H}_{2} \mathrm{O}(3)$, other than one $\mathrm{OH}$ site [2]. The $\mathrm{OH}$ stretching region of the acquired spectrum was fitted to the smallest number of peaks needed for an accurate description of the spectral profile. The 


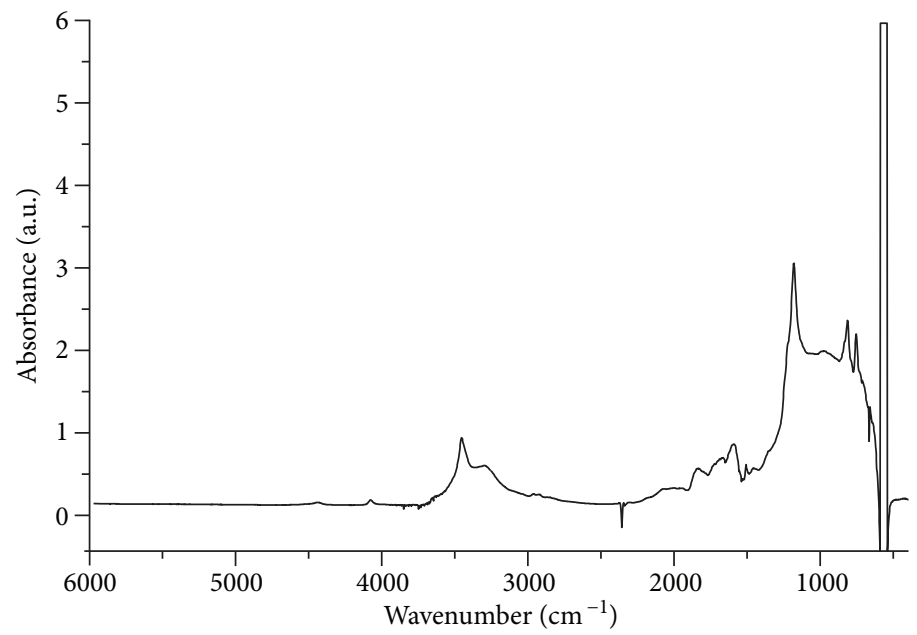

FigURE 1: Micro-FTIR spectrum of charoite collected at room temperature in the range $6000-400 \mathrm{~cm}^{-1}$.

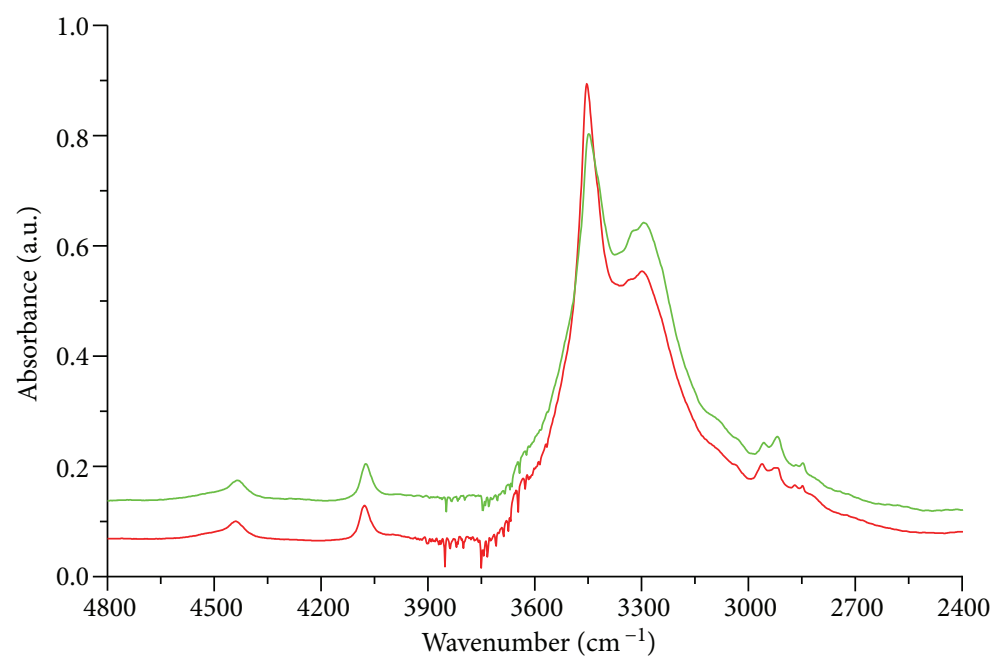

(a)

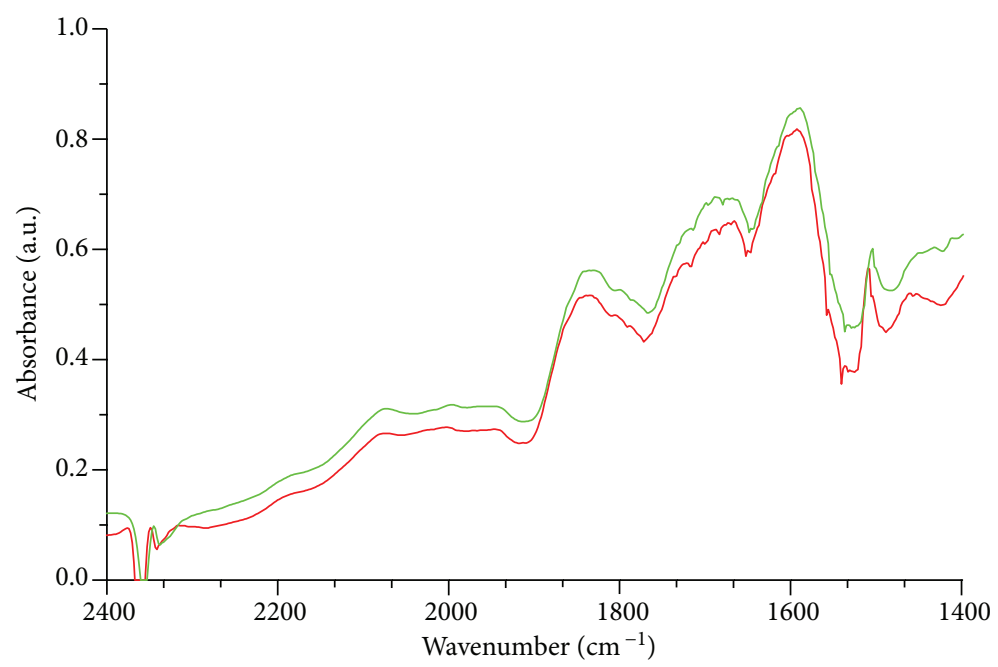

(b)

Figure 2: Micro-FTIR spectra of Figure 1 (red line) compared with that on the same crystal after heating at $100^{\circ} \mathrm{C}$ (green line) in the $4800-$ $2400 \mathrm{~cm}^{-1}$ region (a) and in the $2400-1400 \mathrm{~cm}^{-1}$ range (b). 


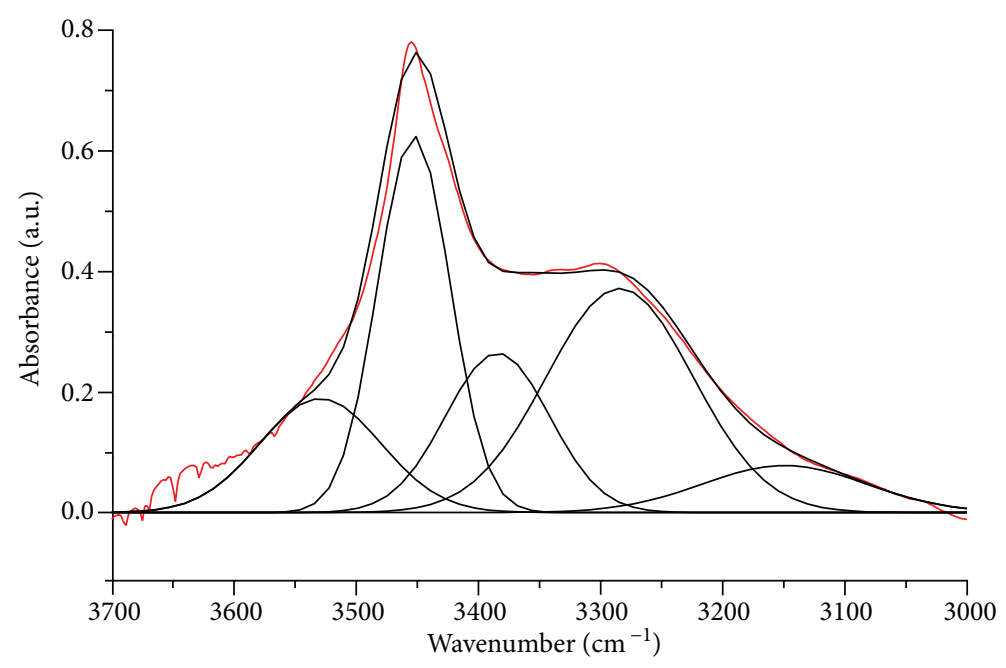

FIGURE 3: Decomposition of the hydrogen stretching modes region for the unheated charoite.

TABLE 1: Band position $\left(\mathrm{cm}^{-1}\right)$ and assignment for the bands in the infrared spectrum of the studied (see Figures 1 and 3 ) and literature charoite.

\begin{tabular}{|c|c|c|c|}
\hline This study & Infrared data [6] & Raman data [5] & Band assignment \\
\hline 4440,4079 & & & - \\
\hline $3530,3453,3385,3285,3150$ & $3610,3550,3500,3410$ & & $\mathrm{OH}$ and $\mathrm{H}_{2} \mathrm{O}$ stretching \\
\hline \multirow[t]{2}{*}{$3036,2965,2922,2870,2849$} & & & C-H vibration \\
\hline & & 2403,2367 & $\mathrm{~N}-\mathrm{H}$ vibration \\
\hline $2077,2005,1948,1841$ & & & Combination of Si-O modes \\
\hline 1667,1595 & $1650,1620,1590$ & & $\mathrm{H}_{2} \mathrm{O}$ bending \\
\hline 1508,1458 & & & C-H vibration \\
\hline $1185,816,759,577$ & & $1135,116,1054,675,638,434,242$ & Si-O and M-O stretching/bending \\
\hline
\end{tabular}

assignment of the resulting five bands (at 3530, 3453, 3385, 3285 , and $3150 \mathrm{~cm}^{-1}$ ) is not straightforward and can be only based on chemical and structural considerations. The three $\mathrm{H}_{2} \mathrm{O}$ molecules in the charoite-90 polytype have different local structural configurations and occupancies [2]. Specifically, the $\mathrm{H}_{2} \mathrm{O}(1)$ molecule, located on the $z$-axes of the tubular chain $\left[\mathrm{Si}_{12} \mathrm{O}_{30}\right]^{12-}$, exhibits low occupancy (0.36) and $<\mathrm{H}_{2} \mathrm{O}(1)-\mathrm{O} \geq 2.82 \AA$; the $\mathrm{H}_{2} \mathrm{O}(2)$ molecule occupies the large tubular chain $\left[\mathrm{Si}_{17} \mathrm{O}_{43}\right]^{18-}$ and shows high occupancy (0.46) and $<\mathrm{H}_{2} \mathrm{O}(2)-\mathrm{O} \geq 2.97 \AA$; the $\mathrm{H}_{2} \mathrm{O}(3)$ molecule is instead located in a tube formed by the bent ribbon $\left[\mathrm{Si}_{6} \mathrm{O}_{17}\right]^{10-}$, two Ca-octahedra, and two Si-tetrahedra. The occupancy of the $\mathrm{H}_{2} \mathrm{O}(3)$ site is 0.36 with $<\mathrm{H}_{2} \mathrm{O}(3)$ $\mathrm{O} \geq 2.99 \AA$. Generally, the shorter the $\mathrm{H}_{2} \mathrm{O}$-O distance, the stronger is the hydrogen bond and the lower is the frequency of the $\mathrm{O}-\mathrm{H}$ stretching band [13]. Therefore, basing on the above crystal chemical considerations, the stretching vibrations of $\mathrm{H}_{2} \mathrm{O}(1), \mathrm{H}_{2} \mathrm{O}(3)$, and $\mathrm{H}_{2} \mathrm{O}(2)$ molecules mainly contribute to the bands at 3285,3385 , and $3453 \mathrm{~cm}^{-1}$, respectively. In addition, the band at $3530 \mathrm{~cm}^{-1}$ can be attributed to stretching vibrations of the $\mathrm{OH}$ groups which substitute for the $\mathrm{O}^{2-}$ at the vertex of the Na-octahedra in the charoite-90 polytype. Finally, the band at $3150 \mathrm{~cm}^{-1}$ well corresponds to the expected position of the Fermi resonance- enhanced overtone of the $\mathrm{H}_{2} \mathrm{O}$ bending mode. This approach in the $\mathrm{OH}$-band assignment of the FTIR spectra of minerals is well consolidated in the literature [14-16].

The obtained micro-FTIR data slightly differ from those previously found for the powder charoite [6]. Indeed, the authors identified, without a fitting analysis, four $\mathrm{OH}$ absorptions shifted to higher wavenumbers with respect to those here reported (see Table 1 ). In addition, absorption essentially centered at about $1620 \mathrm{~cm}^{-1}$ was generally related to water molecules with different energy [6]. This discrepancy may be ascribed to the structural complexity of this mineral which leads to the crystallization of different polytypes sometimes intimately intergrown [2].

Note also that the spectrum in Figure 1 evidences a broad band at about $3000-2800 \mathrm{~cm}^{-1}$ and weak bands at about $1500-1450 \mathrm{~cm}^{-1}$ which are typical of the $\mathrm{C}-\mathrm{H}$ vibrations [17] and may be ascribed to organic matter associated to the charoite fibers. In addition, two distinctive bands appear at about 4440 and $4080 \mathrm{~cm}^{-1}$ whose assignment is unclear. However, their frequency is very close to the combination modes involving the fundamental stretching of $\mathrm{OH}$ group coupled with the Si-O stretching.

As stated above, charoite crystallized jointly with other Ca-bearing alkaline minerals whose framework is based on 
various types of silicate chains. Among these minerals, the frankamenite, $\mathrm{K}_{3} \mathrm{Na}_{3} \mathrm{Ca}_{5}\left[\mathrm{Si}_{12} \mathrm{O}_{30}\right](\mathrm{OH}) \mathrm{F}_{3} \cdot \mathrm{H}_{2} \mathrm{O}$, and the miserite, $\mathrm{K}_{3} \mathrm{Ca}_{10}\left(\mathrm{Ca}, \mathrm{M}^{3+}\right)_{2}\left[\mathrm{Si}_{12} \mathrm{O}_{30}\right]\left[\mathrm{Si}_{2} \mathrm{O}_{7}\right]_{2}(\mathrm{O}, \mathrm{F}, \mathrm{OH})_{2} \cdot \mathrm{H}_{2} \mathrm{O}$, are characterized by the simultaneous presence of the $\mathrm{H}_{2} \mathrm{O}$ molecule and $\mathrm{OH}$ groups in the structure. Accordingly, the FTIR spectrum of frankamenite (registered with the R060100.1 code in the RRUFF database) and that of the miserite [18] exhibits two peaks centered at $\sim 3600$ and $3500 \mathrm{~cm}^{-1}$ which are, respectively, due to stretching vibrations of $\mathrm{OH}^{-}$groups and $\mathrm{H}_{2} \mathrm{O}$ molecules and a unique peak at the characteristic position $\left(\sim 1600 \mathrm{~cm}^{-1}\right)$ of the water bending vibration. On the contrary, in canasite, $\mathrm{K}_{3} \mathrm{Na}_{3} \mathrm{Ca}_{5}\left[\mathrm{Si}_{12} \mathrm{O}_{30}\right](\mathrm{OH}, \mathrm{O})_{2.5} \mathrm{~F}_{1.5}$, and tokkoite, $\mathrm{K}_{2} \mathrm{Ca}_{4}\left[\mathrm{Si}_{7} \mathrm{O}_{18}(\mathrm{OH})\right](\mathrm{F}, \mathrm{OH})$, the hydrogen occurs only as hydroxyl groups. This is also confirmed by the absorption at $\sim 3600 \mathrm{~cm}^{-1}$ and no signal in the water bending region of literature infrared spectra $[6,19]$.

Therefore, the application of the infrared spectroscopy, other than techniques such as X-ray or electron diffraction and microprobe analysis, contributes to discriminate associated minerals with similar structural framework but with different $\mathrm{H}$ speciation.

\section{Conclusions}

Micro-FTIR analysis was performed on a single crystal of charoite whose composition is similar to that reported in the literature [2]. This study contributes in updating the infrared spectroscopic database of a complex mineral specimen such as the one at hand. Indeed, the data here reported complement those previously obtained on powder charoite [6]. Decomposition of the hydrogen stretching region in several bands and analysis of the absorptions at low wavenumbers support the occurrence of $\mathrm{OH}$ groups and more than one $\mathrm{H}_{2} \mathrm{O}$ molecules in the charoite structure as recently found by electron diffraction of charoite90 polytype [2]. The not straightforward assignment of the overlapping bands in the $\mathrm{OH}$ stretching region is due to a combination of the $\mathrm{O}-\mathrm{H}$ stretching vibration modes of hydroxyl groups and water molecules. This also reflects the structural complexity of this mineral which may crystallize in different polytypes with different hydrogen content and speciation [2].

\section{Conflicts of Interest}

The author declares that there are no conflicts of interests regarding the publication of this paper.

\section{Acknowledgments}

This work was supported by the grants from the Italian Ministry of University and Research (PRIN 2010-2011). The author thanks Professor N.V. Vladykin who donated the charoite sample studied in this work. Professor Stefano Poli is acknowledged for the facilities at the Electron Microprobe Laboratory of the Dipartimento di Scienze della Terra, Università di Milano.

\section{References}

[1] E. I. Vorob'ev, Charoite, Academy Publishing 'Geo', Novosibirsk, Russia, 2008.

[2] I. Rozhdestvenskaya, E. Mugnaioli, M. Czank et al., "The structure of charoite, $(\mathrm{K}, \mathrm{Sr}, \mathrm{Ba}, \mathrm{Mn})_{15-16}(\mathrm{Ca}, \mathrm{Na})_{32}\left[\left(\mathrm{Si}_{70}(\mathrm{O}, \mathrm{O}-\right.\right.$ $\left.\left.\mathrm{H})_{180}\right)\right](\mathrm{OH}, \mathrm{F})_{4.0} \cdot n \mathrm{H}_{2} \mathrm{O}$, solved by conventional and automated electron diffraction," Mineralogical Magazine, vol. 74, no. 1, pp. 159-177, 2010.

[3] I. V. Rozhdestvenskaya, E. Mugnaioli, M. Czank, W. Depmeier, U. Kolb, and S. Merlino, "Essential features of the polytypic charoite-96 structure compared to charoite-90," Mineralogical Magazine, vol. 75, no. 6, pp. 2833-2846, 2011.

[4] E. Matesanz, J. Garcia-Guinea, E. Crespo-Feo, P. Lopez-Arce, F. J. Valle-Fuentes, and V. Correcher, "The high-temperature behavior of charoite," The Canadian Mineralogist, vol. 46, no. 5, pp. 1207-1213, 2008.

[5] A. Buzatu and N. Buzgar, "The Raman study of single-chain silicates," in Analele Ştiințifice ale Universității, A. I. Cuza, Ed., vol. 1, Iaşi, Geologie, Tomul LVI, 2010.

[6] V. P. Rogova, Y. G. Rogov, V. A. Drits, and N. N. Kuznetsova, "Charoite, a new mineral, and a new jewelry stone," Zapiski Vsesoyuznogo Mineralogicheskogo Obshchestva, vol. 107, no. 1, pp. 94-100, 1978.

[7] W. Depmeier, "From minerals to materials," in S.V. Krivovichev: Minerals and Advanced Materials II, Springer-Verlag, Berlin Heidelberg, 2012.

[8] N. V. Vladykin, "Potassium alkaline lamproite-carbonatite complexes: petrology, genesis, and ore reserves," Russian Geology and Geophysics, vol. 50, no. 12, pp. 1119-1128, 2009.

[9] A. A. Konev, E. I. Vorob'ev, and K. A. Lazebnik, Mineralogy of Murunskii Alkaline Massif, Nauchno-Izdatelsky Tsentr Ob'edinennogo Instituta Geologii, Geofiziki, Mineralogii, Siberian Branch of Russian Academy of Science, Novosibirsk, Russia, 1996.

[10] G. Della Ventura, F. Bellatreccia, G. C. Parodi, F. Cámara, and M. Piccinini, "Single-crystal FTIR and X-ray study of vishnevite, ideally $\left[\mathrm{Na}_{6}\left(\mathrm{SO}_{4}\right)\right]\left[\mathrm{Na}_{2}\left(\mathrm{H}_{2} \mathrm{O}\right)_{2}\right]\left(\mathrm{Si}_{6} \mathrm{Al}_{6} \mathrm{O}_{24}\right)$," American Mineralogist, vol. 92, no. 5-6, pp. 713-721, 2007.

[11] R. L. Frost and U. Johansson, "Combination bands in the infrared spectroscopy of kaolins-a drift spectroscopic study," Clays and Clay Minerals, vol. 46, no. 4, pp. 466477, 1998.

[12] D. Eisenberg and W. Kauzmann, The Structure and Properties of Water, Oxford University Press, New York, 1969.

[13] E. Libowitzky and G. R. Rossman, "FTIR spectroscopy of lawsonite between 82 and $325 \mathrm{~K}$," American Mineralogist, vol. 81, no. 9-10, pp. 1080-1091, 1996.

[14] F. Scordari, E. Schingaro, G. Ventruti, M. Lacalamita, and L. Ottolini, "Red micas from basal ignimbrites of Mt. Vulture (Italy): interlayer content appraisal by a multi-methodic approach," Physics and Chemistry of Minerals, vol. 35, no. 3, pp. 163-174, 2008.

[15] M. Lacalamita, E. Schingaro, F. Scordari, G. Ventruti, A. Fabbrizio, and G. Pedrazzi, "Substitution mechanisms and implications for the estimate of water fugacity for Ti-rich phlogopite from Mt. Vulture, Potenza, Italy," American Mineralogist, vol. 96, no. 8-9, pp. 1381-1391, 2011.

[16] G. Ventruti, G. Della Ventura, F. Bellatreccia, M. Lacalamita, and E. Schingaro, "Hydrogen bond system and vibrational spectroscopy of the iron sulfate fibroferrite, $\mathrm{Fe}(\mathrm{OH}) \mathrm{SO}_{4} \cdot 5 \mathrm{H}_{2} \mathrm{O}$," 
European Journal of Mineralogy, vol. 28, no. 5, pp. 943-952, 2016.

[17] D. Moro, G. Valdrè, E. Mesto et al., "Hydrocarbons in phlogopite from Kasenyi kamafugitic rocks (SW Uganda): cross-correlated AFM, confocal microscopy and Raman imaging," Scientific Reports, vol. 7, article 40663, 2017.

[18] E. Kaneva, M. Lacalamita, E. Mesto, E. Schingaro, F. Scordari, and N. Vladykin, "Structure and modeling of disorder in miserite from the Murun (Russia) and Dara-i-Pioz (Tajikistan) massifs," Physics and Chemistry of Minerals, vol. 41, no. 1, pp. 49-63, 2014.

[19] N. V. Chukanov, Infrared Spectra of Mineral Species, Springer Geochemistry/Mineralogy, Dordrecht, 2013. 

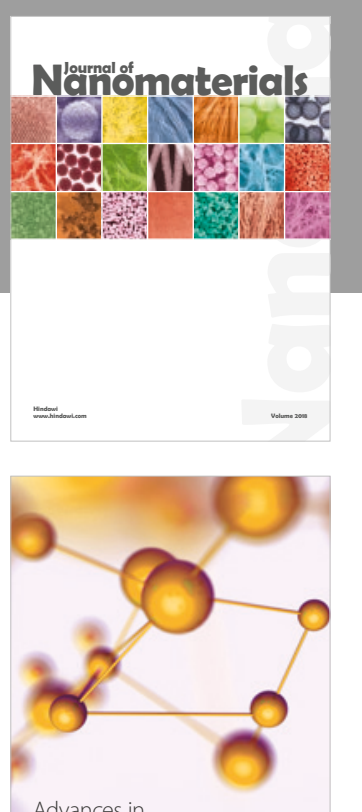

Physical Chemistry
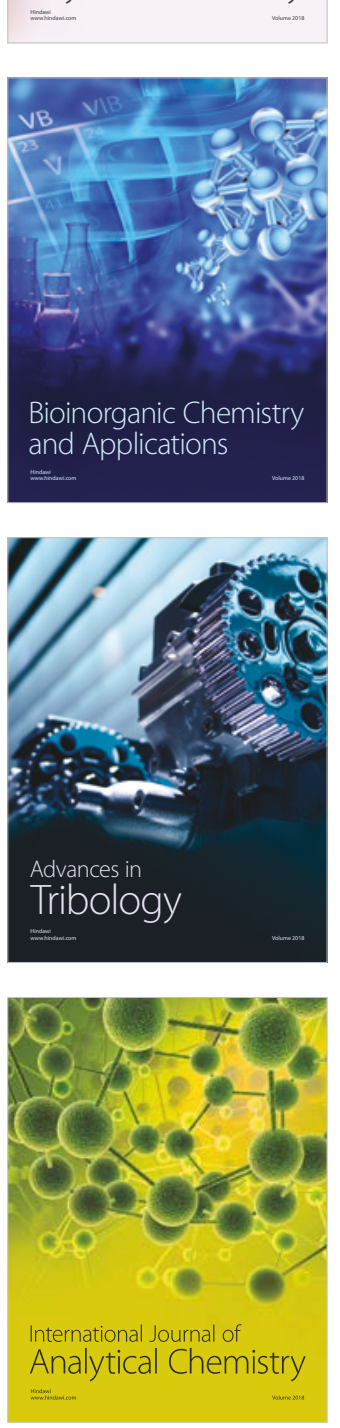

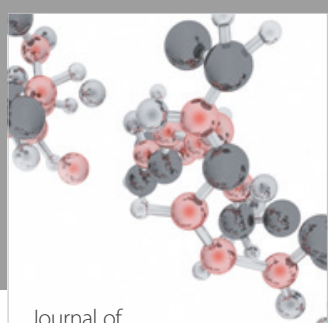

Analytical Methods

in Chemistry

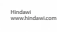

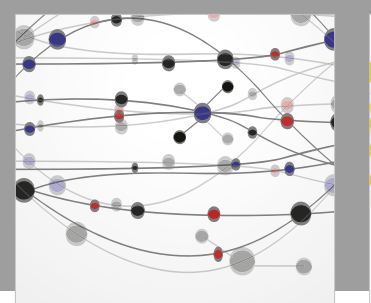

The Scientific World Journal

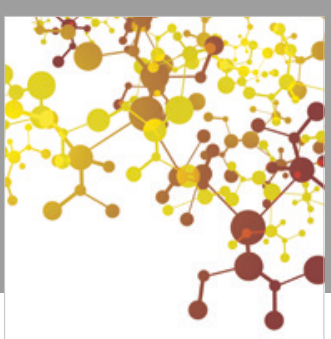

Journal of

Applied Chemistry
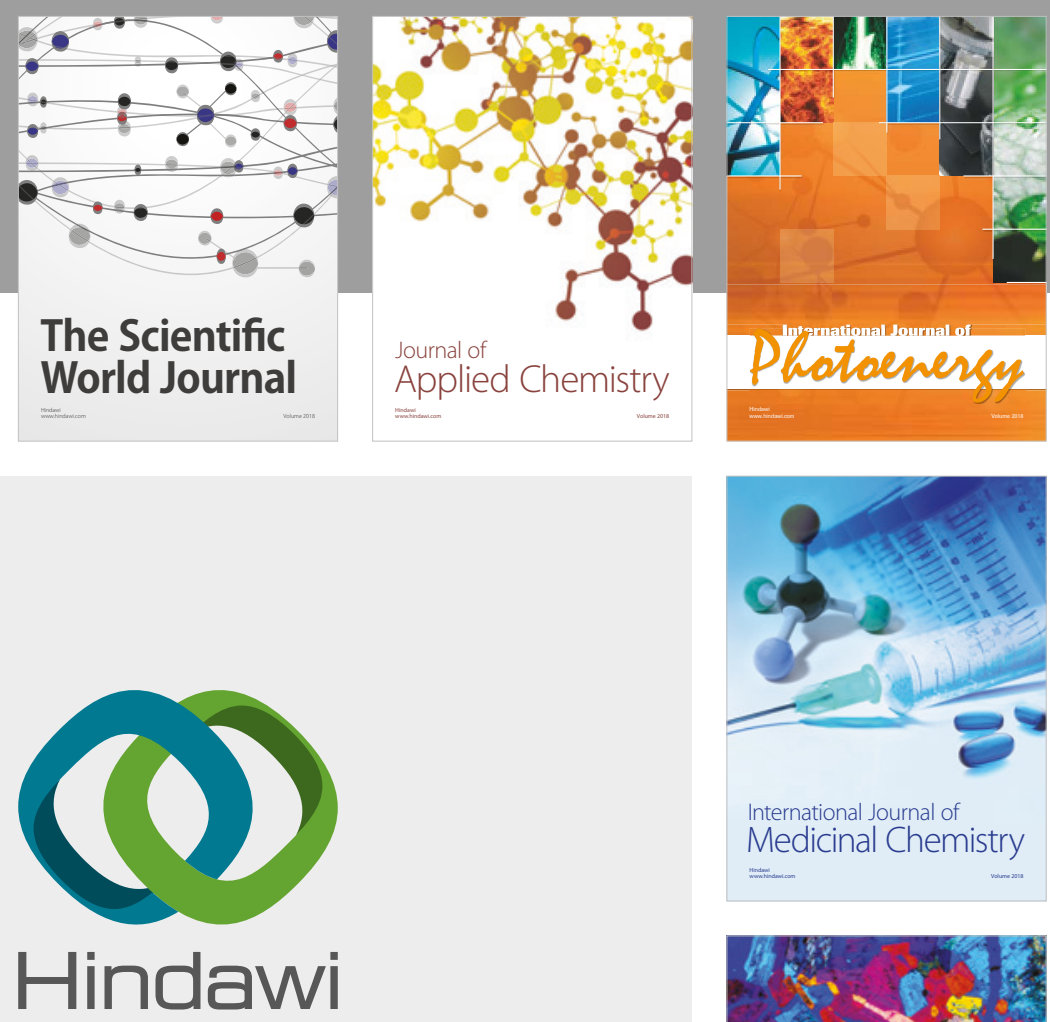

Submit your manuscripts at

www.hindawi.com
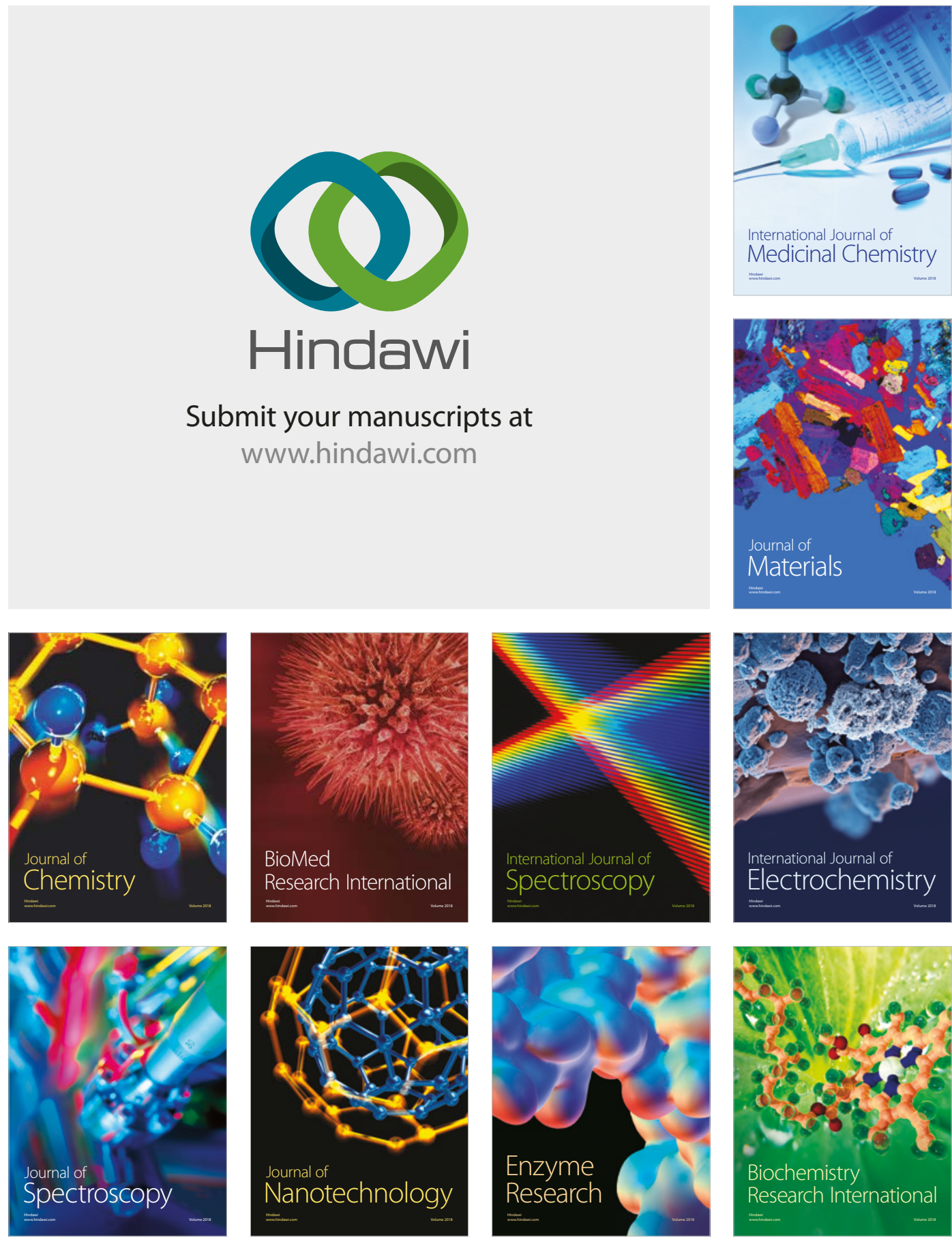
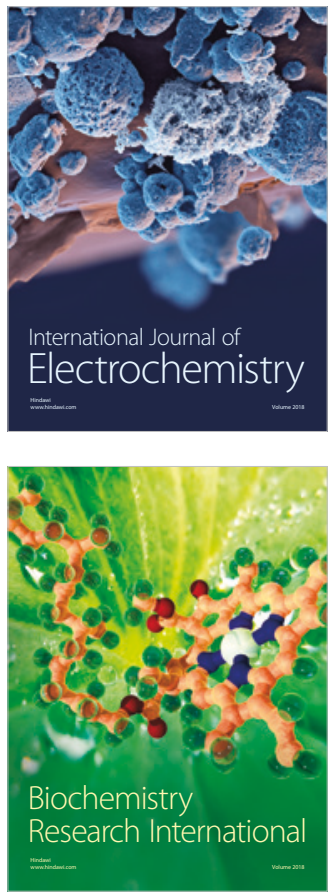